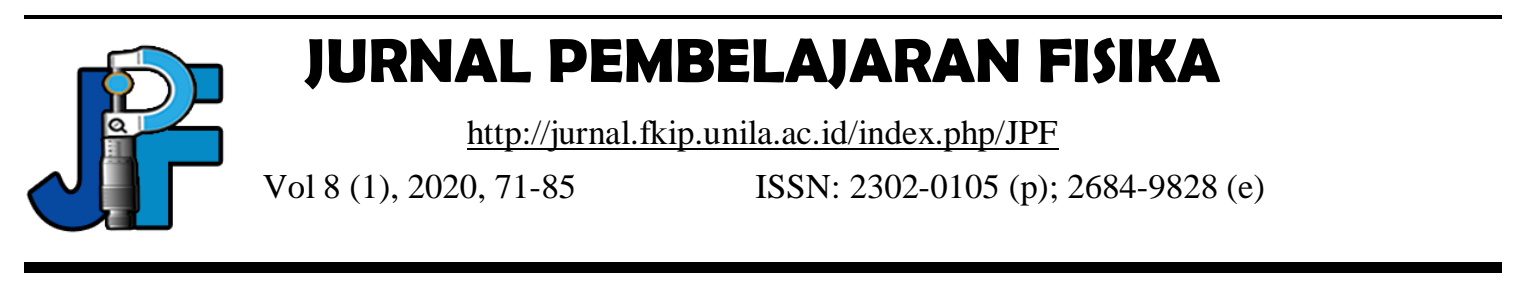

\title{
The Rule of Contextual Teaching and Learning Approach with Problem Solving Method to Students' Critical Thinking Skills on Physics Chapter Work and Energy
}

\author{
Munadhirotul Azizah ${ }^{1}$, Winarti ${ }^{2}$ \\ Department of Physics Education, Sunan Kalijaga State Islamic University, Yogyakarta, Indonesia \\ *e-mail: ${ }^{1}$ munadhirotulazizah12@gmail.com \\ 2winarti@uin-suka.ac.id
}

Received: April 28, 2020

Accepted: June 29, 2020

Published: June 30, 2020

\begin{abstract}
The purpose of this study was to find out: (1) the influence of Contextual Teaching and Learning (CTL) approach with problem solving method to students' critical thinking skills on physics chapter work and energy, (2) the obtained improvement of students' critical thinking skills taught using CTL approach with problem solving method on physics chapter work and energy. This research was a quasi-experimental study with a nonequivalent control group design. The Data collection technique used was technical tests and non-tests. The data analysis technique used was description analysis and parametric statistics with t-test and Normalized Gain (N-gain). The results of this study showed that: (1) the CTL approach with problem solving method had influenced students' critical thinking skills and self-regulation on physics chapter work and energy with a significance level (sig. 2-tailed) of 0.025. This value obtained got smaller value than the significance value $<\alpha=0.05$. It could be said that $\mathrm{H}_{\mathrm{a}}$ was accepted and $\mathrm{H}_{0}$ was rejected, (2) the CTL approach with problem solving method could improve students' critical thinking skills on physics chapter work and energy with 0.603 of N-gain score (in the medium category). Whereas the self-regulation skills based on students' experience revealed an increased metacognition aspect as obtained by the description of students' answers.
\end{abstract}

Keywords: Contextual teaching and learning approach, problem solving method, critical thinking skills, self-regulation, physics chapter work and energy.

DOI: http://dx.doi.org/10.23960/jpf.v8.n1.202008 


\section{INTRODUCTION}

Critical thinking skills are one of higher order thinking skills demand in this era. The skills need are skills of analyzing, arguing, making conclusions using inductive or deductive reasoning, assessing or evaluating and making a decision or solving a problem (Lai, 2011; Purwanto, 2016). Critical thinking skills are needed by learners in solving a learning problem (Facione, 2008; Semiawan, 1992; Wisudawati, 2015).

The PISA (Program for International Student Assessment) report in 2012 stated that the average science score of Indonesian students was 382. It was far from the international mean score which was 500. The difference or score gap between Indonesian students' was quite far in several indicators. These results had placed the Indonesian students' science literacy skills position at 64th place of 65 participating countries (Jamaluddin et al., 2019). One of the reasons for the low science literacy skills rating of Indonesian children was that the questions tested in PISA survey were classified as higher order thinking skills (HOTS) levels. Whereas, in fact, the questions that were commonly tested on Indonesian students were questions with lower order thinking skills (LOTS) levels (Winarti et al., 2016). This statement was supported by the results of an interview at SMA Negeri 5 Yogyakarta which revealed that students were given equations and examples of questions during the learning process. Then, students were then given questions to be solved by themselves. The questions were taken from their textbooks whose cognitive level extended from cognitive levels of $\mathrm{C} 1$ to C3. These types of questions were still included in the LOTS test conducted in Indonesia. That was the basic reason why Indonesian students could not pass good score in PISA since students were not adequately recognizing to think in higher level.

Based on data from the results of the Indonesia National Examination or Ujian Nasional (UN) published by Ministry of Education and Culture in Indonesia in 2017/2018 academic year, the physics average score of students in Yogyakarta was 65.79. The average score had decreased significantly compared to the previous year. The results of the interviews revealed that the majority of learners still had difficulty in working on these questions. Questions that required high analytical skills were considered to be more difficult than ordinary calculation questions (basic mathematics using equation), even rarely the correct answer if students were confronted with these types of problems. Students were weak in analytical and critical thinking skills.

The ability perform analysis is a part of the indicators in critical thinking skills. According to Facione (2008), there are six indicators or aspects of critical thinking skills involved in the process of critical thinking during the lesson. These indicators cover interpretation, analysis, inference, evaluation, explanation and self-regulation skills.

Contextual Teaching and Learning (CTL) approach is one of the learning approaches that are purposed to be able to elevate students' critical thinking skills. The principle of learning using the CTL approach is to construct subject matter with daily life and discover the meaning of the material learned in real life contextually by the learners. For instance, students' conceptual understanding is deeper. As a result, the memory of students taught using the CTL approach is more durable than students who only accept material provided by the teacher (Winarti, 2016). The conceptual understanding then becomes a long term memory. Also, Bahri (2017) research results found that learning CTL can enhance students' critical thinking skills. With the CTL 
approach, it is expected to help students to think in critical way and in comprehensive way to solving the problems. It is necessary to do in the learning process in order to find the meaning from concepts they have received and learned inside and outside the class.

To apply the CTL approach, we tended to apply it with the problem solving method in our study. The problem solving method is also believed to improve students' critical thinking skills. The problem solving method teaches students to be able to solve various problems given by probing the problems first and then solving it. If students are accustomed to solving problems, then their critical thinking skills are indirectly honed because students are required to analyze a problem in order to find information that can be used to solve problems and apply the information to create solution (Lukitasari \& Winarti, 2016). It was supported by the results of the former research which states that the problem solving method can improve students' critical thinking skills (Yanti et al., 2011). Problem solving learning method can train and improve students' skills to solve various problems that require high thinking levels so that they will hone their critical thinking skills (Barnett \& Francis, 2012; Bell \& Loon, 2015; Thomas, 2011).

Based on the explained background, we conducted this study in order to find out: (1) the influence of CTL approach with the use of problem solving method to students' critical thinking skills on physics chapter work and energy, (2) the obtained improvement of students' critical thinking skills taught using CTL approach with the use of problem solving method on physics chapter work and energy. The question research of this study were how CTL approach influence students' critical thinking skills on physics chapter work and energy and what the obtained improvement we got from this study during pretest, post-test and the treatment process.

\section{METHOD}

This research type was quasi experiment using experimental design. The research design was chosen based on non-equivalent control group design. The population of this study was all students of X MIPA class of SMA Negeri 5 Yogyakarta in the 2018/2019 academic year. The sampling technique used in this study is purposive sampling with samples consisting of two study groups namely X MIPA 5 class as an experimental class and X MIPA 6 class as a control class.

The data collection techniques chosen in this study were test and non-test. The test technique used an instrument of critical thinking skills test as a students' sheet test. Meanwhile, the non-test technique was in the form of a self-regulation journal. The instruments used in this study were firstly tested for its validity and reliability. The data analysis technique used in this study was parametric statistics with the t-test, Normalized Gain (N-gain) and descriptive analysis with a significance level of $5 \%$. Statistical analysis tool was using the SPSS 16 application for Windows.

\section{RESULT AND DISCUSSION}

The initial abilities of students in both experimental and control classes were obtained from the pretest score. It was obtained before the two groups received any treatment. The pretest score were then statistically analyzed using the independent t-test using SPSS 16 application. The results of the analysis were presented in Table 1. 
Table 1. The Results of t-test to Pretest Data of Experimental and Control Classes

\begin{tabular}{lcccc}
\multicolumn{1}{c}{ Class } & $\mathbf{N}$ & $\begin{array}{c}\text { Sig. } \\
\text { (2-tailed) }\end{array}$ & $\boldsymbol{\alpha}$ & Interpretation \\
\hline Experimental & 29 & 0.287 & 0.05 & $\begin{array}{c}\text { Both classes } \\
\text { have no } \\
\text { differences }\end{array}$ \\
Control & 29 & & & . \\
\hline
\end{tabular}

Whether there is a difference or no difference in the average pretest score data of the experimental class and the control class can be seen based on the significance value (2-tailed) compared with a significance level of $\alpha$ of $5 \%$ or 0.05 . Based on Table 1 , it can be seen that the value of sig. (2-tailed) was 0.287 . It means that the score is greater than the significance level of $\alpha$ which is 0.05 . It can be said that the students' initial critical thinking skills between the experimental class and the control class before they have taught using CTL with problem solving method as treatment were the same.

Furthermore, differences in the results of students' critical thinking skills between the experimental class and the control class can be seen from the post-test data after the treatment. Post-test data results were analyzed using the independent t-test with the help of SPSS 16 application. The results of the analysis are presented in Table 2.

Table 2. The Results of t-test to Post-test Data of Experimental and Control Classes

\begin{tabular}{lcccc}
\hline \multicolumn{1}{c}{ Class } & $\mathbf{N}$ & $\begin{array}{c}\text { Sig. } \\
(\text { 2-tailed })\end{array}$ & $\boldsymbol{\alpha}$ & Interpretation \\
\hline Experimental & 29 & & & \\
Control & 29 & 0.025 & 0.05 & $\begin{array}{c}\text { Both classes } \\
\text { have differences }\end{array}$ \\
\hline
\end{tabular}

Similar to the results of the independent t-test on pretest data, the presence or absence of differences in the average or mean score of post-test data base on the experimental class and the control class were seen based on the significance value (2tailed) compared with a significance level of $\alpha$ of 0.05 . Based on Table 2, it shows that the value of significance (2-tailed) obtained at 0.025 . It also means that the score obtained is smaller than the significance level of $\alpha$ of 0.05 . These values indicate a significant difference in students' critical thinking skills. It was obtained between the experimental class and the control class after being given the CTL approach with problem solving method as a learning treatment in this study. There is an improvement in the results due to the pretest and post-test session during this study conducted.

\section{The Influence of CTL Approach with Problem Solving Method to Students' Critical Thinking Skills}

Based on research that has been done and the results of data analysis, it can be seen that the CTL approach with problem solving method as a learning treatment in this 
study in learning physics on physics chapter work and energy can lead to be affecting students' critical thinking skills. It can also be proven through statistical data on the results of testing the respective hypothesis (Table 1 and Table 2). Based on the results of normality test data from both pretest and post-test score data, it is known that the data is normally distributed. It means that data testing can be done with a parametric statistical test, which is in this study using an independent t-test to obtain the differences.

Independent t-test conducted on the pretest data of students' critical thinking skills results in the average conclusion of students' critical thinking skills in the experimental class and the control class. Both classes have not possessed much difference. It means that $\mathrm{H}_{0}$ in this study is accepted. Table 1 provides the preliminary information that the initial critical thinking skills before treatment of the experimental class and control class students are relatively the same according to statistics.

Post-test data tested by independent t-test results in rejection of $\mathrm{H}_{0}$. Rejection of $\mathrm{H}_{0}$ provides the information that the average or mean critical thinking skills score of students taught using the CTL approach with problem solving method are better than the average or mean critical thinking skills score of students taught using expository learning. The results of this hypothesis test concluded that the use of the CTL approach with problem solving method in the experimental class had a significant influence to improve students' critical thinking skills compared to expository learning in the control class. Both classes have different result in the improvement of HOTS.

\section{Improvement in Students' Critical Thinking Skills Taught Using CTL Approach with Problem Solving Method}

Improvement in students' critical thinking skills can be obtained from the average or mean or $\mathrm{N}$-gain score. The results of calculating and analysing the average or mean of N-gain score of students' critical thinking skills are presented in Table 3.

Table 3. Description on Mean of N-gain Score

\begin{tabular}{lcccc}
\hline \multicolumn{1}{c}{ Class } & $\begin{array}{c}\text { Mean of Pretest } \\
\text { Score }\end{array}$ & $\begin{array}{c}\text { Mean of Post- } \\
\text { test Score }\end{array}$ & $\begin{array}{c}\text { Mean of } \\
\text { N-Gain }\end{array}$ & Category \\
\hline Experimental & 63.10 & 85.59 & 0.603 & Medium \\
Control & 65.27 & 81.34 & 0.452 & Medium \\
\hline
\end{tabular}

Based on Table 3, the $\mathrm{N}$-gain score of the experimental class is greater than the $\mathrm{N}$-gain score of the control class. The experimental class has an $\mathrm{N}$-gain of 0.603 while the control class has an $\mathrm{N}$-gain score of 0.452 . Even though the quantitative $\mathrm{N}$-gain of the experimental class is greater, the $\mathrm{N}$-gain interpretation of both the experimental class and the control class is in the moderate or medium category. Therefore, further tests are needed to find out how much improvement has occurred in the class. The test used if there is a similarity in the N-gain categorization is the effect size. After further analysis, the effect size value of 0.67 is obtained. Based on the interpretation of the effect size coefficient according to Cohen, the value is too, in the medium category. 
Based on the results of hypothesis testing using independent $t$ test statistics, it can be seen that there is a recall of students' critical thinking skills after getting different treatment. The difference in the increase in students' critical thinking skills between the experimental class and the control class can be seen in the average description of the $\mathrm{N}$ gain value (Table 3). It shows that the $\mathrm{N}$-gain value of the experimental class is higher than the control class. This is reinforced by the difference in students' post-test answers between the experimental class and the control class. There are differences in the results of students' post-test answers between the experimental class and the control class. For example, the following are some of the results of the post-test answers of the experimental class and control class students with the same critical thinking indicators.

Table 4. Description of N-gain Score to Critical Thinking Skills Indicators

\begin{tabular}{|c|c|c|c|c|}
\hline \multirow{2}{*}{ Critical Thinking Skills Indicators of Facione } & \multirow{2}{*}{ Items } & \multicolumn{3}{|c|}{$\begin{array}{c}\mathrm{N}-\text { Gain of } \\
\text { Experimental Class }\end{array}$} \\
\hline & & Min. & Max. & Mean \\
\hline Interpretation: & & & & \\
\hline $\begin{array}{l}\text { Understanding and expressing the interpretation or } \\
\text { meaning of the problems. }\end{array}$ & 1 & 0.00 & 1.00 & 0.73 \\
\hline $\begin{array}{l}\text { Analysis: } \\
\text { Identifying and determining the correlation between } \\
\text { statement, question, concept, description or other forms. }\end{array}$ & 2 & 0.00 & 1.00 & 0.49 \\
\hline $\begin{array}{l}\text { Inference: } \\
\text { Identifying and utilizing the materials needed to infer or } \\
\text { conclude the problems. }\end{array}$ & 3 & -0.40 & 1.00 & 0.66 \\
\hline $\begin{array}{l}\text { Evaluation: } \\
\text { Determining credibility from various statements or } \\
\text { representation and able to logically valuing the } \\
\text { correlation between statement, description and concept. }\end{array}$ & 4 & -0.33 & 1.00 & 0.43 \\
\hline $\begin{array}{l}\text { Explanation: } \\
\text { Applying and giving the scientific reason logically based } \\
\text { on the results. }\end{array}$ & 5 & 0.00 & 1.00 & 0.64 \\
\hline
\end{tabular}

Table 4 provides information that the experimental class students experienced an increase in $\mathrm{N}$-gain for all questions. However, if we pay close attention, there is an $\mathrm{N}$ gain value with a negative form and an $\mathrm{N}$-gain value of 0.00 . The negative $\mathrm{N}$-gain value is found in two critical thinking indicators, namely inference and evaluation. The $\mathrm{N}$-gain value of 0.00 is found in the indicators of critical thinking interpretation, analysis and explanation. The negative $\mathrm{N}$-gain value indicates that there is a decrease in the post-test value against the pretest value, while the $\mathrm{N}$-gain value of 0.00 indicates that the student did not experience an increase in score from the pretest to the post-test. The negative $\mathrm{N}$ gain value and $0.00 \mathrm{~N}$-gain value are the minimum $\mathrm{N}$-gain values of the entire $\mathrm{N}$-gain value. This means that there are only a few students whose value is fixed and has decreased in the post-test value against the pretest value, while many other students have experienced an increase in the post-test value for the pretest value. 
Based on the brief explanation from Table 4, we will deliberately discuss the results of the students' critical thinking skills improvement in more detail of changes. The improvements that occur in students will be discussed further based on each indicator of critical thinking skills of Facione due to our obtained results.

\section{a. Interpretation}

In the interpretation indicator of Facione theory in critical thinking skills, students are required to be able to categorize, differentiate, or explain the purpose of the images related to problems given during the lesson. Problem number 1 had presented 4 different pictures and students were asked to determine which images do the work (W) and which images do not do the work (W). Then they were asked to give scientific reasons or arguments based on the answers chosen below the answer sheet.

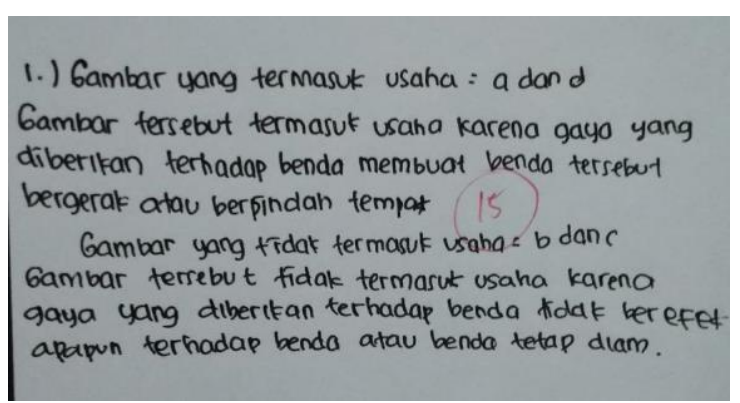

(a)

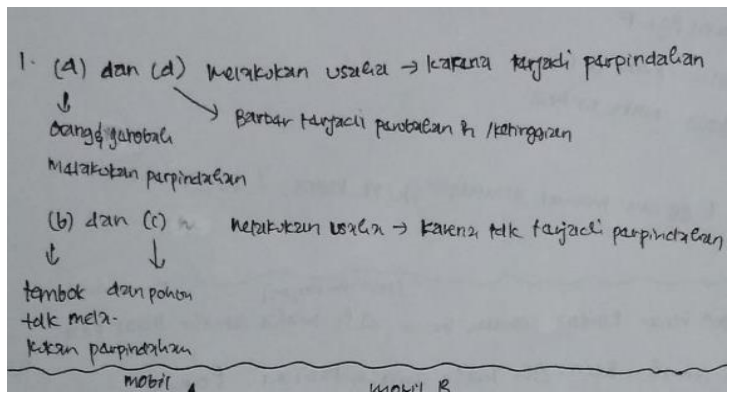

(b)

Figure 1. The Students' Answer in Post-test of Interpretation Indicator; (a) Students' Answer in Post-test from Control Class, (b) Students' Answer in Post-test from Experimental Class

Figure 1 is the result of students' post-test answers to the critical thinking skills in interpretation indicator of item test. In Figure 1, both the control class and the experimental class had given the correct answer and included arguments or scientific reasoning for choosing the picture. Yet, there were differences in the way of delivering arguments between students of the experimental class and the control class.

Students in the control class gave an argument by stating that objects had to do work (W) due to a movement (s) and had not done a work (W) because there was no movement (s). While the students of the experimental class gave an argument in more detail, namely mentioning the direction of the movement by including $\Delta \mathrm{h}$ which means a change in height on the barbell. This indicates the difference in thinking skills between the two students. Students of the experimental class were able to write answers in more detail, which means that their critical thinking skills were sharpened.

\section{b. Analysis}

In the analysis indicator, students were guided to identify and conclude the relationships between concepts given. In this indicator, the improvement score was only 0.49. After deeper identification, it was found out that there were two possible causes for students' mistakes in answering questions. The first cause was students did not understand the questions given carefully. The second cause was students were confused 
about how to solve the problems given by the questions because students were never trained to solve problems that required critical thinking during the learning process.

There was a difference in the ability of the analysis conducted by students of the experimental class and the control class influenced by the learning activities carried out. When the learning process was held using the CTL approach with problem solving method, the teacher presented problems that required analysis and critical thinking. In addition, the teacher also reminded students with statements that emphasized students to be more careful in working on problems that required analysis, such as "Be careful when dealing with questions that require analysis, if what is asked is to identify and conclude the relationship, then what written is a description of the results of the analysis that you do". Unlike the case with the control class, the teacher did not give a statement like the experimental class but teachers only allowed students to practice working on the questions from their printed books so that the analytical skills of the control class had not been well developed like the way students in experimental class did.

\section{c. Inference}

In inference indicator, the skills that students must possess are identifying and using the elements needed to draw conclusions (Facione, 2008). This indicator was the most difficult to achieve in this study because sometimes these inference skills were obtained by students from experience and the phenomenon that was found in daily life. This is also in accordance with the results of the Himawan \& Winarti (2018) and Mutakinati et al., (2018) research that found the formation of students' concepts came from what students encountered from their daily environment and sometimes wrong reception lead to incorrect understanding and concepts. Meanwhile, finding from former research also found that inference indicator was most likely to not be gained (Anggraini et al., 2018). Thus other finding revealed that they were able to elevate inference indicator through some exercises in physics problems (Pertiwi, 2012).

\section{d. Evaluation}

The expected skills of students in the evaluation indicator are being able to assess the credibility of various statements or representations and being able to logically understand and get the relationship between statements, descriptions, questions and concepts. One of the questions given for this indicator was to present the problem as follows: "When an object is moved from a place with a low height (above ground level) to a higher place, its potential gravitational energy will increase, whereas as the object approaches the surface earth, its potential energy will decrease. But the potential energy possessed by the spring will increase when pulled or pressed." then the students were asked to assess the truth of the statement and gave their scientific or logical reason.

When students took pretest and post-test, a statement about a physical concept related to daily life was presented, then they were asked to create and analyze the truth of the statement using logical and in-depth arguments and scientific reasoning based on contextual observations due to their daily experience. The results of the post-test answers of the control class students in question number 4 can be seen in Figure 2 (a) while the results of the post-test answers of the experimental class students in question number 4 can be seen in Figure 2 (b). From both answers, we can see the difference. 

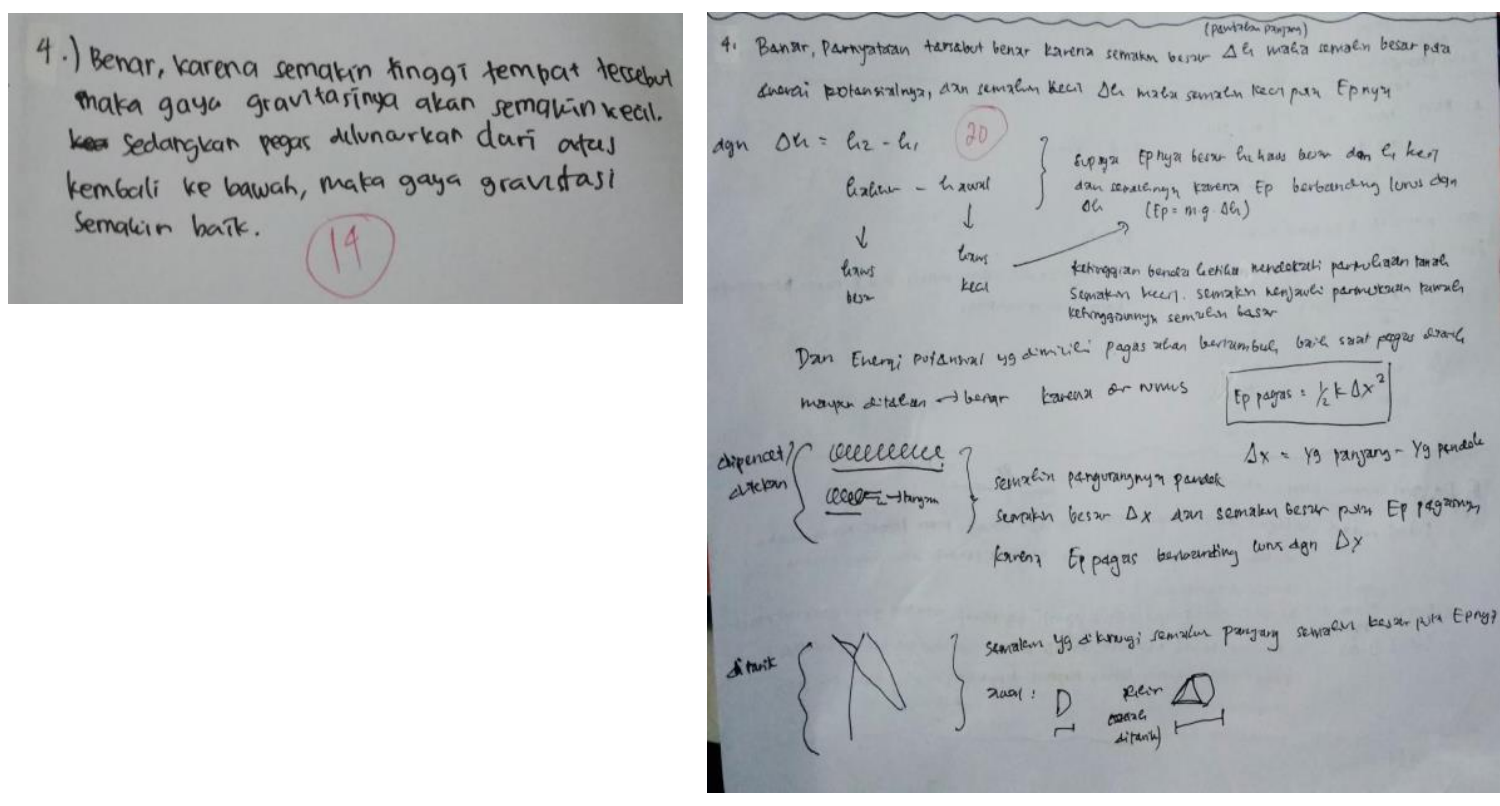

(a)

(b)

Figure 2. The Students' Answer in Post-test of Evaluation Indicator; (a) Students' Answer in Post-test from Control Class, (b) Students' Answer in Post-test from Experimental Class

Control class students seemed to be able to provide an assessment (true / false) of the statement given but the reasons given to strengthen his judgment were less precise. The reason for gravitational potential energy (Ep) was good enough but still not right. Gravitational potential energy (Ep) was indeed influenced by the mass of the object, the acceleration of the objects' gravity and the height of the object according to the equation. If it only touched on the gravitational force which was getting bigger, then the reason was less precise because the context in this problem was its height.

The reason given for the elastic elastics potential energy of the spring was also not right. Students gave the same reason with gravitational potential energy which was about the greater gravitational force. Whereas the spring context in this problem was not related to gravity but it was related to the change in spring length. This was consistent with the elastic spring potential energy equation. When giving reasons in the second statement about elastic potential energy, it could be inferred that students did not really understand the concept of elastic potential energy in springs. Students from control class in this case still assumed that elastic potential energy was the same as gravitational potential energy which depended on the acceleration of gravity of the earth.

Unlike the case with the answers given by the control class students, the experimental class students gave detailed and thorough answers. The analysis and arguments provided were quite in-depth. This indicated the critical thinking skills of students began to honed and in synced well. The results of the post-test answers of the experimental class students can be seen in Figure 2 (b). The answers in Figure 2 (b) show that the experimental class students were capable of providing an assessment of 
the statements presented. The reason given was also very precise with regard to the concepts of gravitational potential energy and elastic potential energy. In addition, the argument given was also profound, even students were able to correctly describe what was analogous to the problem in the statement about the spring. When analyzed in depth, it appeared that students could understand the intentions of the problem well and properly, so students were able to solve and answer questions perfectly.

Differences in answers given by students of the experimental class and the control class could occur because when learning in the experimental class using the CTL approach with problem solving method, students were taught to solve problems by using the problem solving steps correctly (probing then solving). At the stage of understanding the problem, students were taught to be able to understand what the real intentions of a problem were. So, students could draw up a problem solving plan appropriately and solve problems correctly, so that when faced with problems that required critical thinking and high analysis, students had no difficulty to solve them.

\section{e. Explanation}

In the explanation indicator of Facione critical thinking skills, students are expected to be able to determine and give a logical reason based on the results obtained (Facione, 1990). The explanation indicator was stated and related in question number 5 of pretest and post-test. In question number 5, students were faced with the problem of a slingshot. Students were asked to explain what energy conversions happened in the slingshot game and gave a logical reason. The results of the post-test answer number 5 students in the experimental class and the control class were presented in Figure 3.

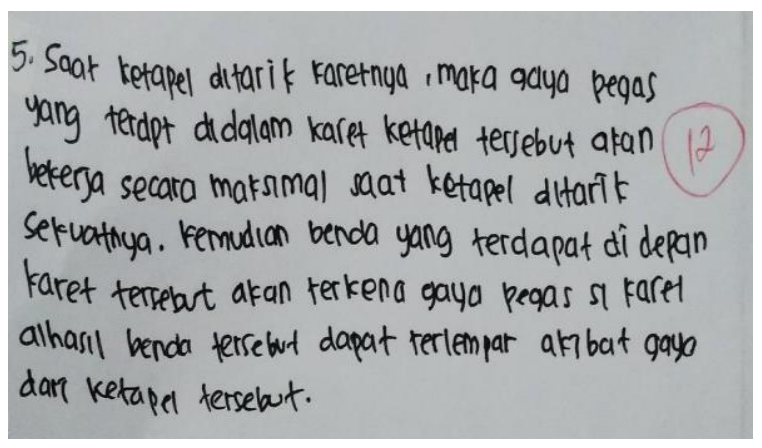

(a)

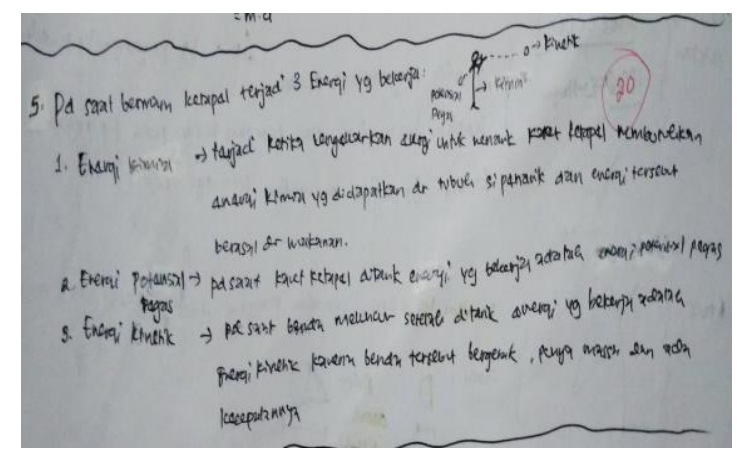

(b)

Figure 3. The Students' Answer in Post-test of Explanation Indicator; (a) Students' Answer in Post-test from Control Class, (b) Students' Answer in Post-test from Experimental Class

Based on Figure 3, there was a difference in students' answers from the control class and the experimental class. Control class students gave answers about the spring force experienced by slingshot rubber. The answers given were only limited to the analogy of logic and were not included in the concept of physics. Students alluded to the spring force on a slingshot, even though the expected and correct answer to the problem was to explain what energy conversion happened in the slingshot game. Also, students were required to explain their logical reason and scientific reasoning to this problem.

Unlike the case with the answers given by the control class students, the experimental class students were able to provide detailed answers and explain them 
clearly based on the physics concepts they had learned. Students gave answers about the three types of energy conversion that occured in slingshot, namely chemical energy, elastic potential energy (spring) and kinetic energy. Students also explained in detail and thoroughly the location of the three energies in the slingshot game. The explanation given by students was quite in-depth. This indicated that students understood well the physical concept of the law of conservation of mechanical energy, so that they were able to explain in detail and properly the locations of energy conversion.

The difference in answers given by students of the two different groups was inseparable from the treatment received while learning in class. In the experimental class, the learning process was always carried out by using CTL approach with problem solving method so that students were able to think contextually to relate the learning objects with daily phenomenon in real life. The purpose of this contextual learning was designed so that students could find the meaning of why they should understand the material learned. For instance, students were able to be more understand in receiving contextual concepts as if the results of the construction that was done by themselves. Thus, they would continue to remind the concepts as long term memory by students as they got to know and find the concepts by solving the problem. In addition, it was also assisted by solving problems related to daily life, so that students' critical thinking skills were increasingly honed. This was very useful when students were faced with a problem that required high analytical skills. So, students can solve the problem properly alongside with their former knowledge that was remembered well. In contrast, the teacher did not give treatment to the control class as the experimental class. Learning process in the control class was only limited to explaining the material. Students were working on the questions contained in the book comprehensively, so the critical thinking skills of the control class students were not honed well and properly.

\section{f. Self-regulation}

Assessment of students' self-regulation skills was done by giving a selfregulation journal sheet to students in both classes. Journal of self-regulation was given before students were taught with treatment (pretest) and after students got treatment (post-test). This self-regulation journal aimed to find out the increasing self-regulation skills of students who used the CTL approach with the problem solving method.

It was supported by the finding of former research that found students were more discipline when they were facing the problem-based question. Moreover, when the questions were contextual, students were obtained to hold their understanding in a long term memory (Suyanto and Wahyudi, 2019). Other finding by Rahayu et al., (2018) revealed that self-regulation in CTL classroom had influenced the learning outcomes.

Based on the results of the self-regulation journal analysis, it was known that the aspects of motivation and behavior of students showed consistency in answering journal questions. This could be seen from the answers of students in the pretest and post-test which were relatively the same. For example, in journal number 5, students were asked about what strategies they were carried out in order to understand the material well. In pretests, $52.17 \%$ of students answered by learning, asking questions, and practicing questions. Meanwhile, in post-test, $70 \%$ of students also answered the journal chores by learning, asking questions, and practicing questions (more in the appendix). Both of 
these answers were answers that dominated among other answers. Figure 4 were the examples of students' answers on behavioral aspects of self-regulation journal.

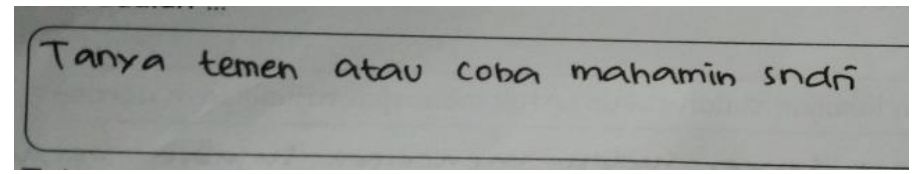

(a)

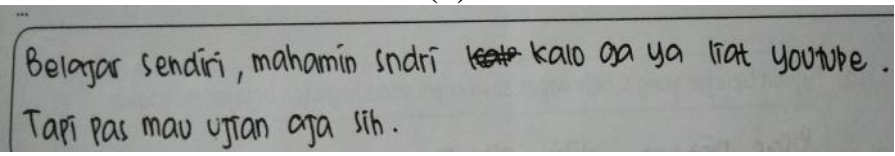

(b)

Figure 4. The Students' Answer in Post-test of Self-regulation Indicator; (a) Students' Answer in Post-test from Control Class, (b) Students' Answer in Post-test from Experimental Class

The consistency of students in answering the journal questions showed that students' self-regulation skills in the aspects of motivation and behavior had been formed in such a way and properly. This means that students were able to evaluate and monitor their cognition in aspects of motivation and behavior. The next example was the time when students were asked about how to decide and determine one of the various choices on physics chapter work and energy. The answers given at the time of the pretest were as much as $35.71 \%$ answered thought and the rest amount of percentage was analyzed way. Meanwhile, the amount of $35.71 \%$ of students at post-test answered the items by looking at statements, formulas and concepts that were more appropriate. The rest of $28.57 \%$ of students had answered the items by reading, understanding, concluding and deciding. These answers were answers that dominated among other answers based on the results we had obtained from students' journal. Figure 5 showed the further and in-depth answer of students in answering the self-regulation journal related to metacognition indicator. The answers were quite different.

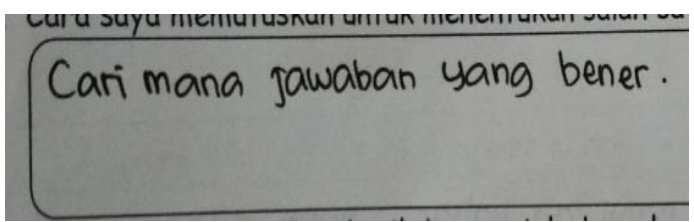

(a)

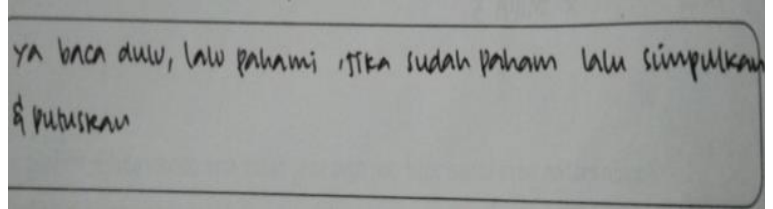

(b)

Figure 5. The Students' Answer in Self-regulation Journal of Metacognition Indicator; (a) Students' Answer in Post-test from Control Class, (b) Students' Answer in Post-test from Experimental Class

The difference in answers showed that students' self-regulation skills on the aspect of metacognition experience changed from pretest to post-test. The answers given by students in the pretest were still general in nature and had not answered the journal statement in detail or in-depth. While the answers given by students at the time of the posttest were sufficiently detailed and were able to answer journal questions well. This shows that students had increased their self-regulation skills after treatment.

Based on the description above, it can be said that students' self-regulation skills in the aspects of motivation and behavior at the time of the pretest and post-test were 
good. This showed that students can already evaluate and monitor their cognition in aspects of motivation and behavior while in the aspect of metacognition, students' selfregulation skills had increased from pretest to post-test. It could be seen by the difference in answers given by students at the pretest and post-test in both classes. The consistency of students' answers on aspects of motivation and behavior due to selfregulation skills basically must be owned by everyone. This is in accordance with the theory put forward by Adler in Alwisol (2004) which states that everyone had the power to freely create their own lifestyle. Man himself is responsible for who he is and how he behaves. Humans have the creative power to control their lives, take responsibility for their final goals, determine how to fight for these goals and contribute to the development of social interests. Based on Adlers' opinion, it can be seen that each individual has the basic ability to control himself, in accordance with the ability that exists in him to take responsibility in accordance with his life goals.

\section{CONCLUSION}

This research came to conclude these several findings: (1) it was obtained and found that the CTL approach using the problem solving method had influenced the way students think critically (students' critical thinking skills) and the way students behave themselves during the lesson (students' self-regulation) on physics chapter work and energy with a significance level (sig. 2-tailed) of 0.025 . The value obtained from our results got smaller value than the significance value $<\alpha=0.05$. It could be said that $\mathrm{H}_{\mathrm{a}}$ was accepted and $\mathrm{H}_{0}$ was rejected, (2) the CTL approach with problem solving method could improve students' critical thinking skills on physics chapter work and energy with 0.603 of $\mathrm{N}$-gain score (in the medium category). Whereas the self-regulation skills based on students' experience revealed an increase of metacognition indicators from obtained questions in journal. It was obtained in the description of students' answers. 


\section{REFERENCES}

Alwisol, A. (2004). Psikologi kepribadian. Malang: Universitas Muhammyadiah Malang.

Anggraini, R., Herlina, K., \& Nyeneng, I. D. P. (2018). Desain LKPD Berbasis Scientific Approach Untuk Melatih Keterampilan Berpikir Kreatif Siswa Pada Materi Suhu dan Perubahannya : Penelitian Pendahuluan. Jurnal Pembelajaran Fisika, 6(2).

Bahri, S. (2017). Penerapan Model Pembelajaran Contextual Teaching And Learning (Ctl) Dalam Meningkatkan Kemampuan Berpikir Kritis Peserta Didik Di Madrasah Bandar Lampung. Al-Tadzkiyyah: Jurnal Pendidikan Islam, 8(1), 4559.

Barnett, J. E., \& Francis, A. L. (2012). Using higher order thinking questions to foster critical thinking: A classroom study. Educational Psychology, 32(2), 201-211.

Bell, R., \& Loon, M. (2015). The impact of critical thinking disposition on learning using business simulations. The International Journal of Management Education, 13(2), 119-127.

Facione, N. C., \& Facione, P. A. (2008). Critical thinking and clinical judgment. Critical Thinking and Clinical Reasoning in the Health Sciences: A Teaching Anthology, 1-13.

Facione, P. A. (1990). The California Critical Thinking Skills Test--College Level. Technical Report\# 1. Experimental Validation and Content Validity.

Himawan, N. A., \& Winarti, W. (2018). THE STRATEGY OF METACOGNITION TO IMPROVE PROBLEM SOLVING COMPETENCY IN KINETIC THEORY OF GASES. EDUSAINS, 10(2), 265-274.

Indonesia, B. F., \& Lukitasari, C. A. (2016). Efektivitas Model Pembelajaran Search, Solve, Create and Share (Sscs) Untuk Meningkatkan Keterampilan Berpikir Kritis Siswa Kelas X Man Yogyakarta I Pada Materi Alat-Alat Optik. Berkala Fisika Indonesia, 8(1), 17-28.

Jamaluddin, J., Jufri, A. W., Ramdani, A., \& Azizah, A. (2019). Profil Literasi Sains dan Keterampilan Berpikir Kritis Pendidik IPA SMP. Jurnal Penelitian Pendidikan IPA, 5(1).

Lai, E. R. (2011). Critical thinking: A literature review. Pearson's Research Reports, 6, $40-41$.

Mutakinati, L., Anwari, I., \& Kumano, Y. (2018). Analysis of students' critical thinking skill of middle school through stem education project-based learning. Jurnal Pendidikan IPA Indonesia, 7(1), 54-65.

Pertiwi, D. (2012). Jurnal pembelajaran fisika. 1(September), 77-85.

Purwanto, J. P. (2016). Profil Pembelajaran Fisika dan Kemampuan Berpikir Kritis Siswa Madrasah Aliyah se-DIY. Jurnal Penelitian Pembelajaran Fisika, 7(1), $8-18$. 
Rahayu, S. M., Ertikanto, C., \& Wahyudi, I. (2018). Pengaruh Pengunaan Modul Kontekstual Berbasis Multirepresentasi Pada Pembelajaran Hukum Gravitasi Newton Terhadap Hasil Belajar Siswa. Jurnal Pembelajaran Fisika, 6(1), 4758.

Semiawan, C. R. (1992). Pengembangan kurikulum berdiferensiasi. PT Gramedia Widiasarana.

Suyanto, E., \& Wahyudi, I. (2019). PENGEMBANGAN LEMBAR KERJA PESERTA DIDIK BERBASIS CTL PADA MATERI FLUIDA DINAMIS SMA KELAS XI. Jurnal Pendidikan Fisika (JPF), 7(1), 81-92.

Thomas, T. (2011). Developing first year students' critical thinking skills. Asian Social Science, 7(4), 26.

Winarti, Cari, Suparmi, Widha Sunarno, E. I. (2016). Preface: International Conference on Recent Trends in Physics (ICRTP 2016). Journal of Physics: Conference Series, 755(1), 0-5. https://doi.org/10.1088/1742-6596/755/1/011001

Winarti, W. (2016). Contextual Teaching and Learning (CTL) untuk Meningkatkan Kemampuan Berpikir Kreatif Siswa. Jurnal Pendidikan Fisika Dan Keilmuan (JPFK), 1(1), 1-8.

Wisudawati, A. W. (2015). Eka sulistyowati. Metodologi Pembelajaran IPA, Jakarta: Bumi Aksara.

Yanti, R., Sumardi, S., \& Suryana, Y. (n.d.). Pengaruh Pendekatan Pemecahan Masalah terhadap Kemampuan Berpikir Kritis Siswa pada Penyelesaian Soal Cerita Matematika. PEDADIDAKTIKA: Jurnal Ilmiah Pendidikan Guru Sekolah Dasar, 5(1), 319-337. 